\title{
Comparative studies of photochemical cross-linking methods for stabilizing the bulk hetero-junction morphology in polymer solar cells
}

Carlé, Jon Eggert; Andreasen, Birgitta; Tromholt, Thomas; Vesterager Madsen, Morten; Norrman, Kion; Jørgensen, Mikkel; Krebs, Frederik C

Published in:

Journal of Materials Chemistry

Link to article, DOI:

$10.1039 / \mathrm{c} 2 \mathrm{jm} 34284 \mathrm{~g}$

Publication date:

2012

Document Version

Publisher's PDF, also known as Version of record

Link back to DTU Orbit

Citation (APA):

Carlé, J. E., Andreasen, B., Tromholt, T., Vesterager Madsen, M., Norrman, K., Jørgensen, M., \& Krebs, F. C. (2012). Comparative studies of photochemical cross-linking methods for stabilizing the bulk hetero-junction morphology in polymer solar cells. Journal of Materials Chemistry, 22(46), 24417-24423.

https://doi.org/10.1039/c2jm34284g

\section{General rights}

Copyright and moral rights for the publications made accessible in the public portal are retained by the authors and/or other copyright owners and it is a condition of accessing publications that users recognise and abide by the legal requirements associated with these rights.

- Users may download and print one copy of any publication from the public portal for the purpose of private study or research.

- You may not further distribute the material or use it for any profit-making activity or commercial gain

- You may freely distribute the URL identifying the publication in the public portal 


\title{
Comparative studies of photochemical cross-linking methods for stabilizing the bulk hetero-junction morphology in polymer solar cells $\dagger$
}

\author{
Jon Eggert Carlé, Birgitta Andreasen, Thomas Tromholt, Morten V. Madsen, Kion Norrman, Mikkel Jørgensen \\ and Frederik C. Krebs*
}

Received 3rd July 2012, Accepted 14th August 2012

DOI: $10.1039 / \mathrm{c} 2 \mathrm{jm} 34284 \mathrm{~g}$

We are here presenting a comparative study between four different types of functionalities for crosslinking. With relatively simple means bromine, azide, vinyl and oxetane could be incorporated into the side chains of the low band-gap polymer TQ1. Cross-linking of the polymers was achieved by UV-light illumination to give solvent resistant films and reduced phase separation and growth of PCBM crystallites in polymer:PCBM films. The stability of solar cells based on the cross-linked polymers was tested under various conditions. This study showed that cross-linking can improve morphological stability but that it has little influence on the photochemical stability which is also decisive for stable device operation under constant illumination conditions.

\section{Introduction}

Research on polymer solar cells (PSC) has reportedly delivered an increase in the power conversion efficiency to some $10 \%$ by optimization of each component and especially in the case of the active layer composed of a light harvesting polymer and a molecular acceptor. ${ }^{1,2}$ Another aspect that needs to be addressed is the stability of these devices, which has also improved by several orders of magnitude during the last decade. ${ }^{3}$ Modern PSC rely on a so-called bulk hetero-junction where the polymer-acceptor mixture in the active layer is micro-phase segregated to form a bicontinuous structure with channels for both electron and hole transport. A key issue is that the excitons formed upon irradiation with light have a limited diffusion length in these materials of $10-20 \mathrm{~nm}$, which means that this is also the optimal physical dimension of the domains in the hetero-junction. Unfortunately, this is not usually the thermodynamic equilibrium (i.e. the material is metastable), which is manifested in a growth of PCBM acceptor crystallites that erodes the optimal morphology. ${ }^{4,5}$

Several strategies have been developed to mitigate this problem. One of the first proposed was to combine the donor polymer with the acceptor part to create block-copolymers that form stable bi-continuous networks by supra-molecular forces. ${ }^{6-8}$ This approach has not been so successful, presumably due to the formidable synthetic challenges. Another strategy is to cross-link the active layer after it has been deposited by a crosslinking reaction. One possibility that has been explored is to use side chains that are attached to the polymer with tertiary ester

Department of Energy Conversion and Storage, Technical University of Denmark, Frederiksborgvej 399, DK-4000 Roskilde, Denmark. E-mail: frkr@dtu.dk

$\uparrow$ Electronic supplementary information (ESI) available. See DOI: $10.1039 / \mathrm{c} 2 \mathrm{jm} 34284 \mathrm{~g}$ groups that can be cleaved off by a thermal treatment of the processed films. The residual carboxylic acid groups then form hydrogen bonds resulting in a very stiff matrix that also immobilizes the acceptor part. ${ }^{9}$ Yet another approach that is also explored in this work is to incorporate cross-linkable groups in some of the polymer side chains. Several different photo-curable groups have been used for this purpose such as oxetane groups, ${ }^{10}$ alkyl-bromide, ${ }^{11,12}$ azide ${ }^{13-15}$ and vinyl. ${ }^{16,17}$ The idea is once again that the cross-linking immobilizes the structure inhibiting further growth of domains.

Previous studies have each focused on one specific cross-linking reaction only. This study compares four different types of functionalities for cross-linking attached to a low band-gap polymer TQ1. ${ }^{18,19}$ Furthermore, experiments have been carried out in an inert atmosphere and with hot dark storage between measurements to enhance the thermally induced morphological instability. Finally, different experimental conditions aimed for degradation were compared in order to investigate the importance of morphological stability compared to photochemical stability.

\section{Experimental}

Synthesis

2,5-Bis-(trimethylstannyl)-thiophene, ${ }^{20} \quad 3,3^{\prime}$-(5,8-dibromoquinoxaline-2,3-diyl)diphenol (1) and TQ1 were synthesized according to the procedures described in the literature. ${ }^{18}$

5,8-Dibromo-2,3-bis(3-(8-bromooctyloxy)phenyl)quinoxaline (2b). Compound 1 ( $1 \mathrm{~g}, 2.118 \mathrm{mmol}$ ), 1,8-dibromooctane (5.76 g, 21.18 $\mathrm{mmol})$ and potassium carbonate $(1.464 \mathrm{~g}, 10.59 \mathrm{mmol})$ were dissolved in DMSO $(20 \mathrm{ml})$. The mixture was stirred at $50{ }^{\circ} \mathrm{C}$ under argon overnight. Water was added and the organic phase was 
extracted with ethyl acetate. The organic phase was washed three times with water and dried over $\mathrm{MgSO}_{4}$. The crude product was added to a silica column and eluted with heptane-ethyl acetate to give the product as a solid. Yield $32.1 \%(580 \mathrm{mg}, 0.679 \mathrm{mmol}) .{ }^{1} \mathrm{H}$ NMR (500 MHz, $\left.\mathrm{CDCl}_{3}\right) \delta 7.92(\mathrm{~s}, 2 \mathrm{H}), 7.30-7.20(\mathrm{~m}, 4 \mathrm{H}), 7.16(\mathrm{~m}$, $2 \mathrm{H}), 6.99-6.85(\mathrm{~m}, 2 \mathrm{H}), 3.87(\mathrm{t}, J=6.5 \mathrm{~Hz}, 4 \mathrm{H}), 3.42(\mathrm{t}, J=6.8 \mathrm{~Hz}$, $4 \mathrm{H}), 1.93-1.79(\mathrm{~m}, 4 \mathrm{H}), 1.79-1.64(\mathrm{~m}, 4 \mathrm{H}), 1.50-1.27(\mathrm{~m}, 16 \mathrm{H}) .{ }^{13} \mathrm{C}$ NMR $\left(126 \mathrm{MHz}, \mathrm{CDCl}_{3}\right) \delta 159.05,154.00,139.32,139.17,133.11$, $129.32,123.72,122.60,116.54,115.77,77.27,77.02,76.77,68.02$, $33.95,32.80,29.17,29.08,28.72,28.12,25.94$.

5,8-Dibromo-2,3-bis(3-(undec-10-enyloxy)phenyl)quinoxaline (2c). Prepared as for $\mathbf{2 b}$ : compound $\mathbf{1}$ (500 mg, $1.059 \mathrm{mmol}$ ), 11-bromoundec-1-ene $(617 \mathrm{mg}, 2.65 \mathrm{mmol})$ and potassium carbonate (1464 mg, $10.59 \mathrm{mmol}$ ) were dissolved in DMSO (10 ml). Yield 87\% (715 mg, $0.921 \mathrm{mmol}) .{ }^{1} \mathrm{H} \mathrm{NMR}\left(500 \mathrm{MHz}, \mathrm{CDCl}_{3}\right) \delta 7.93(\mathrm{~s}, 2 \mathrm{H})$, $7.29-7.23(\mathrm{~m}, 4 \mathrm{H}), 7.23-7.17(\mathrm{~m}, 2 \mathrm{H}), 6.96(\mathrm{~m}, 2 \mathrm{H}), 5.84(\mathrm{dd}, J=$ 17.0, $10.3 \mathrm{~Hz}, 2 \mathrm{H}), 5.06-4.90(\mathrm{~m}, 4 \mathrm{H}), 3.88(\mathrm{t}, J=6.6 \mathrm{~Hz}, 4 \mathrm{H}), 2.07$ $(\mathrm{dd}, J=14.5,6.8 \mathrm{~Hz}, 4 \mathrm{H}), 1.83-1.68(\mathrm{~m}, 4 \mathrm{H}), 1.50-1.21(\mathrm{~m}, 26 \mathrm{H})$. ${ }^{13} \mathrm{C}$ NMR $\left(126 \mathrm{MHz} \mathrm{CDCl}_{3}\right) \delta 159.09,154.03,139.33,139.18$, 133.06, 129.30, 123.74, 122.56, 116.61, 115.82, 114.13, 68.15, 33.79, $29.54,29.44,29.35,29.13,28.95,26.02$.

5,8-Dibromo-2,3-bis(3-(6-((3-ethyloxetan-3-yl)methoxy)hexyloxy)phenyl)quinoxaline (2d). Prepared as for $\mathbf{2 b}$ : compound $\mathbf{1}$ (500 mg, $1059 \mathrm{mmol})$, 3-((6-bromohexyloxy)methyl)-3-ethyloxetane $(739 \mathrm{mg}, 2.65 \mathrm{mmol})$ and potassium carbonate $(1464 \mathrm{mg}$, $10.59 \mathrm{mmol})$ were dissolved in DMSO $(10 \mathrm{ml})$. Yield $80 \%(740$ $\mathrm{mg}, 0.852 \mathrm{mmol}) .{ }^{1} \mathrm{H} \mathrm{NMR}\left(500 \mathrm{MHz}, \mathrm{CDCl}_{3}\right) \delta 7.91(\mathrm{~s}, 2 \mathrm{H})$, $7.24(\mathrm{~m}, 4 \mathrm{H}), 7.19-7.11(\mathrm{~m}, 2 \mathrm{H}), 7.00-6.84(\mathrm{~m}, 2 \mathrm{H}), 4.45$ (d, $J=$ $5.8 \mathrm{~Hz}, 4 \mathrm{H}), 4.37(\mathrm{~d}, J=5.8 \mathrm{~Hz}, 4 \mathrm{H}), 3.88(\mathrm{t}, J=6.5 \mathrm{~Hz}, 4 \mathrm{H})$, $3.53(\mathrm{~s}, 4 \mathrm{H}), 3.47(\mathrm{t}, J=6.6 \mathrm{~Hz}, 4 \mathrm{H}), 1.74(\mathrm{q}, J=7.4 \mathrm{~Hz}, 8 \mathrm{H})$, $1.66-1.58(\mathrm{~m}, 4 \mathrm{H}), 1.50-1.35(\mathrm{~m}, 8 \mathrm{H}), 0.89(\mathrm{t}, J=7.5 \mathrm{~Hz}, 6 \mathrm{H})$. ${ }^{13} \mathrm{C}$ NMR $\left(126 \mathrm{MHz}, \mathrm{CDCl}_{3}\right) \delta 159.09,153.98,139.30,139.20$, $133.08,129.28,123.73,122.61,116.53,115.82,78.57,73.55$, $71.51,68.02,43.50,29.54,29.12,26.80,25.97,25.89,8.15$.

\section{General procedure for the Stille cross-coupling polymerization}

Monomer $\mathbf{2 a}$ and one of the monomers $\mathbf{2 b}, \mathbf{2} \mathbf{c}$ or $\mathbf{2 d}$ (9: 1 molar ratio) and 2,5-bis(trimethylstannyl)thiophene were mixed in degassed toluene to give a $0.04 \mathrm{M}$ solution. To this was added a catalyst mix of $2 \mathrm{~mol} \%$ tris(dibenzylideneacetone)dipalladium( $(0)$ and $8 \mathrm{~mol} \%$ tri-o-tolylphosphine. The solution was stirred at $100{ }^{\circ} \mathrm{C}$ for at least 48 hours to complete the polymerization. The crude polymer was then precipitated by adding the reaction mixture to a large volume of methanol. The polymers were purified by Soxhlet extraction, first with methanol, then with hexane and finally with chloroform. The chloroform fraction was then precipitated by pouring it into 10 times the volume of methanol. The precipitate was filtered off and dried in vacuum to give the purified polymer.

Polymer TQ-Br. Monomers 2b (100 mg, $0.117 \mathrm{mmol})$, 2a (734 mg, $1.053 \mathrm{mmol}$ ) and 2,5-bis(trimethylstannyl)thiophene (480 mg, $1.170 \mathrm{mmol})$. Yield $620 \mathrm{mg}(83 \%)$.
Polymer TQ-Vinyl. Monomers 2c (50 mg, $0.064 \mathrm{mmol}$ ), 2a (404 $\mathrm{mg}, 0.579 \mathrm{mmol}$ ) and 2,5-bis(trimethylstannyl)thiophene (264 mg, $0.644 \mathrm{mmol})$. Yield $370 \mathrm{mg}(91 \%)$.

Polymer TQ-Oxetane. Monomers 2d (50 mg, $0.058 \mathrm{mmol})$, 2a (361 mg, $0.518 \mathrm{mmol}$ ) and 2,5-bis(trimethylstannyl)thiophene (236 mg, $0.576 \mathrm{mmol})$. Yield $330 \mathrm{mg}(90 \%)$.

Polymer TQ-N 3 . TQ-Br (300 mg, $0.483 \mathrm{mmol}$ ) was dissolved in toluene $(100 \mathrm{ml})$ at $100{ }^{\circ} \mathrm{C}$ and sodium azide (314 $\left.\mathrm{mg}, 4.83 \mathrm{mmol}\right)$ in DMF (100 ml) was added slowly. The mixture was stirred at $100{ }^{\circ} \mathrm{C}$ under argon for 48 hours. The solvents were removed under reduced pressure and the polymer redissolved in chloroform and precipitated in methanol. The polymer was purified by Soxhlet extraction first with methanol then with chloroform and finally precipitated in methanol. Yield: $290 \mathrm{mg}(95 \%)$.

\section{Device fabrication}

The polymers TQ1, TQ-Br, TQ-Vinyl, TQ-Oxetane or TQ-N and [60]PCBM (Solenne b.v., The Netherlands) were dissolved separately in chlorobenzene $\left(20 \mathrm{mg} \mathrm{ml}^{-1}\right)$ and stirred overnight at $50{ }^{\circ} \mathrm{C}$. The polymer and PCBM solutions were mixed and further stirred at $50{ }^{\circ} \mathrm{C}$ and then filtered $(1 \mu \mathrm{m}$ pore size $)$. To the TQ-Oxetane blend was added $5 \%$ (by weight) of the photoacid generator (bis(4-tert-butylphenyl)iodonium $p$-toluenesulfonate) (Sigma-Aldrich). The prefabricated ITO coated glass substrates were first ultrasonically cleaned in water and then in 2-propanol. Zinc oxide nanoparticles $(\mathrm{ZnO})$, prepared according to the literature, ${ }^{21}$ were spin-coated from water onto the ITO covered substrate at $1000 \mathrm{rpm}$ and annealed at $140{ }^{\circ} \mathrm{C}$ for 10 minutes. The active layer, composed of the polymer:PCBM solution, was spincoated at $700 \mathrm{rpm}$ onto the $\mathrm{ZnO}$ layer followed by UV-irradiation at $254 \mathrm{~nm}$ with a laboratory lamp (commonly employed for thin layer chromatography) for 10 minutes in a glove box to cross-link the polymer. A PEDOT:PSS (Agfa EL-P 5010) solution was then spin-coated on top at $2800 \mathrm{rpm}$ followed by annealing at $110^{\circ} \mathrm{C}$ for 2 minutes. The devices were transferred to a vacuum chamber where silver electrodes were applied by thermal evaporation at a pressure below $10^{-6} \mathrm{mbar}$. The active area of the devices was $0.25 \mathrm{~cm}^{2}$.

\section{Optical microscopy}

Blends (1:1 by weight) of the polymers and [60]PCBM in chlorobenzene $\left(20 \mathrm{mg} \mathrm{ml}^{-1}\right)$ were spin-coated on glass slides at $700 \mathrm{rpm}$. The samples were then treated with UV-irradiation $(254 \mathrm{~nm})$ for 10 minutes in a glove box using a hand held lamp. The samples were then annealed in ambient air for 13 hours at $150{ }^{\circ} \mathrm{C}$. Optical micrographs of the samples were acquired before and after the annealing procedure.

\section{Photochemical degradation studies}

Photochemical stabilities were evaluated using a fully automated, high capacity degradation setup with an AM1.5G spectrum in the ambient atmosphere at $1000 \mathrm{~W} \mathrm{~m}^{-2}$ described elsewhere. ${ }^{22}$ Each polymer was spin-coated on glass substrates from a chlorobenzene solution. The spin coating parameters were adjusted in order to obtain a film thickness of around $60 \mathrm{~nm}$. 
Quantification of the degradation rate was based on the evolution of the gradual decrease of UV-visible absorbance, which was recorded at 20 min intervals.

\section{Results and discussion}

\section{Synthesis of cross-linkable versions of TQ1}

We selected the low band gap polymer TQ1 for creating crosslinkable versions. The typical octyloxy side chains on the diphenyl-quinoxaline monomer can easily be substituted with alkyl groups adorned with azide, bromine, vinyl or oxetane functionalities that can be used for photocross-linking reactions. These types of cross-linking functionalities have previously been investigated with the purpose of stabilizing the morphology in other types of PSC. ${ }^{10-16}$

The syntheses of the monomers and the polymerization of the five polymers studied in this work are outlined in Scheme 1.

One of the reasons for choosing the TQ1 system for this work was the relatively straightforward preparation of the functionalized monomers. The key was the synthesis of the starting material quinoxaline 3,3'-(5,8-dibromoquinoxaline-2,3-diyl)diphenol (1) that is common to all the monomers, which is prepared from the known 5,8-dibromo-2,3-bis(3-methoxyphenyl)quinoxaline ${ }^{18}$ by cleaving of the methyl groups with concentrated hydrobromic acid. The different quinoxaline monomers were then prepared by alkylation at the phenolate functions with either 1-bromooctane or a substituted alkyl bromide as shown in Scheme 1. Polymerization reactions to give either TQ1 or the co-polymers $\mathbf{T Q - B r}$,
TQ-Vinyl and TQ-Oxetane were performed through a Stille coupling either between pure 2a and 2,5-bis(trimethylstannyl)thiophene or using a mixture of $\mathbf{2} \mathbf{a}$ and one of the monomers $\mathbf{2} \mathbf{b}-\mathbf{d}$. A monomer feed ratio of $\mathbf{2} \mathbf{b}-\mathbf{d}$ to $\mathbf{2 a}$ was chosen to be $1: 9$ which should secure several cross-linkable groups per polymer chain. The synthesis of TQ- $\mathbf{N}_{\mathbf{3}}$ was carried out by treating $\mathbf{T Q}-\mathbf{B r}$ with sodium azide in hot toluene-DMF, replacing bromine with an azide group. This transformation is clearly observed by ${ }^{1} \mathrm{H}$ NMR of the polymers. The polymers were characterized by size exclusion chromatography (SEC) with THF as the eluent, using polystyrene as the standard (see Table 1), and also by ${ }^{1} \mathrm{H}$ NMR (see ESI Fig. S1-5†).

\section{Cross-linking experiments}

The four different photoactive groups used in this study are expected to cross-link via different chemical reaction mechanisms when initiated by UV exposure (254 nm). The bromo-alkyl group is presumably cleaved homolytically to give an alkyl radical and a bromine atom ${ }^{23}$ while the alkyl azide group splits off molecular nitrogen $\left(\mathrm{N}_{2}\right)$ leaving an alkyl nitrene. ${ }^{24,25}$ The highly reactive nitrene can then react with either the polymer or the fullerene in the bulk through an addition reaction to double bonds. ${ }^{26}$ The reactions of the vinyl and the oxetane groups are slightly more speculative. The oxetane ring undergoes cross-linking initiated by a photoacid generator (PAG). The propagation probably involves ring-opening of the oxetane through an attack of another oxetane group, as shown in Scheme 2. ${ }^{27}$<smiles>[R]Oc1cccc(-c2nc3c(Br)ccc(Br)c3nc2-c2cccc(O[R])c2)c1</smiles>
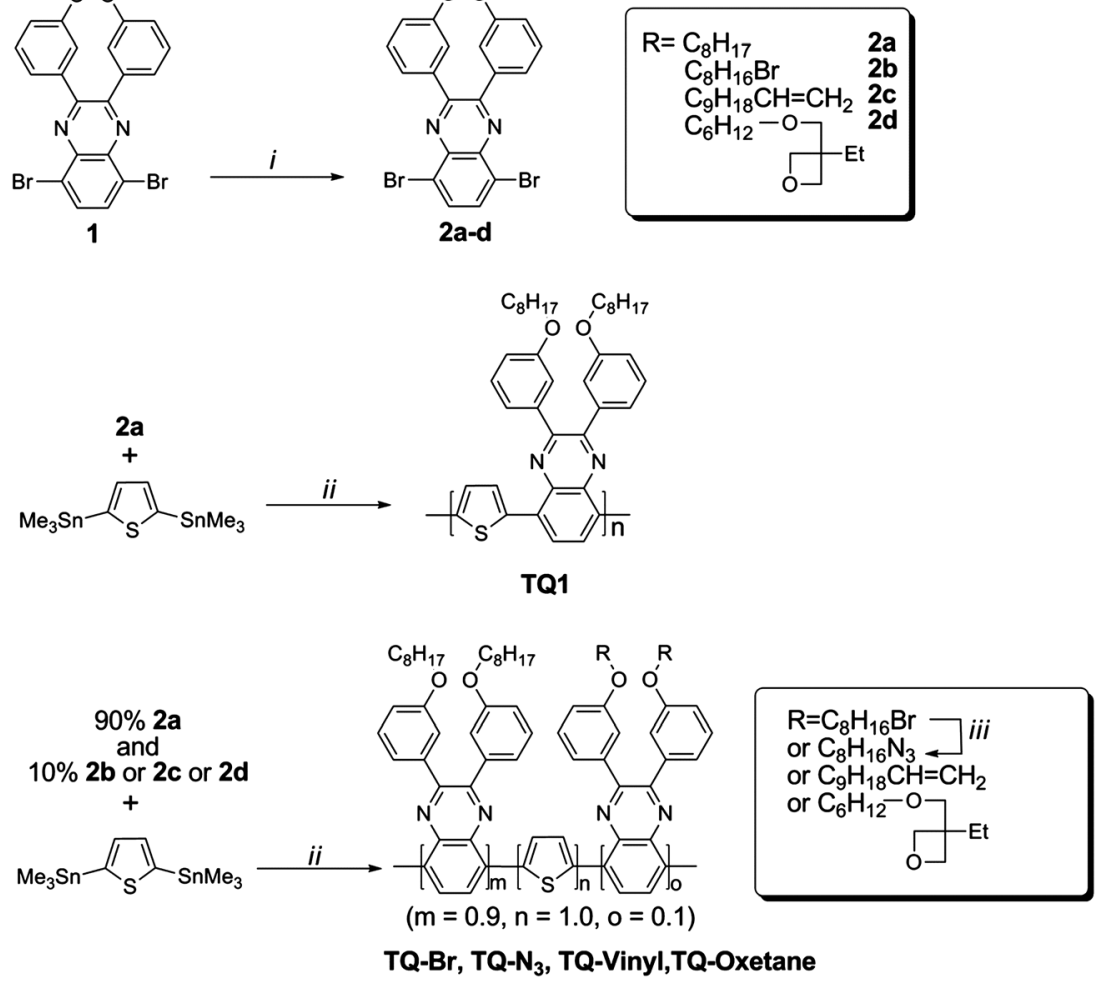

Scheme 1 Synthesis of the monomers 2a-d and subsequent polymerization with 2,5-bis-(trimethylstannyl)-thiophene to give the polymers with different

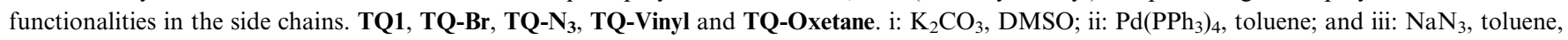
DMF. 
Table 1 Molecular weight and optical data for the five polymers

\begin{tabular}{lllllll}
\hline Polymer & $M_{\mathrm{n}}(\mathrm{kDa})$ & $M_{\mathrm{w}}(\mathrm{kDa})$ & $\mathrm{PD}$ & $\lambda_{\max }(\mathrm{nm})$ & $E_{\mathrm{g}}^{\text {opt }}(\mathrm{eV})$ & $\begin{array}{l}\lambda_{\max }(\mathrm{nm}) \\
\text { cross-linked }\end{array}$ \\
\hline TQ1 & 37.7 & 174.8 & 4.6 & $364 / 623$ & 1.7 & $\begin{array}{l}E_{\mathrm{g}}^{\text {opt }}(\mathrm{eV}) \\
\text { cross-linked }\end{array}$ \\
TQ-Br & 20.7 & 67.0 & 3.23 & $364 / 624$ & 1.7 & $364 / 622$ \\
TQ-N & 22.7 & 92.2 & 4.1 & $360 / 621$ & 1.7 & $363 / 618$ \\
TQ-Vinyl & 23.7 & 86.8 & 3.66 & $361 / 623$ & 1.7 & $363 / 620$ \\
TQ-Oxetane & 22.1 & 90.1 & 4.1 & $361 / 623$ & 1.7 & $364 / 620$ \\
\hline
\end{tabular}
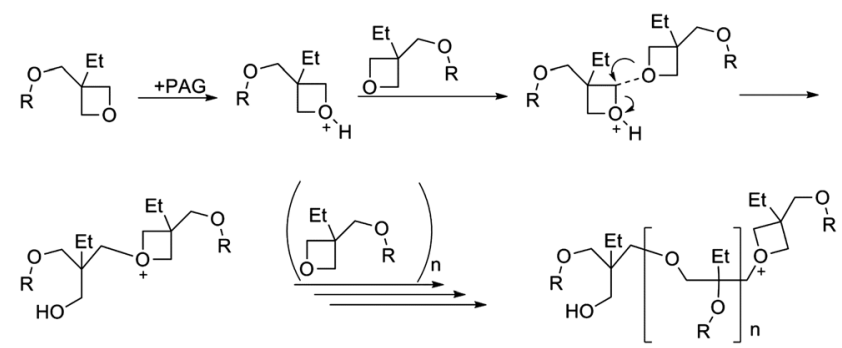

Scheme 2 A possible mechanism for cross-linking of oxetane through a ring opening polymerization. $\mathrm{Et}=$ ethyl, $\mathrm{R}=$ polymer and $\mathrm{PAG}=$ photoacid generator.

In all cases reactive intermediates are formed that can react fast with neighboring groups in the film. These may be on other polymer strands giving rise to cross-linking of the polymer matrix and/or with PCBM cross-linking the donor-acceptor domains.

Each of the five polymers was spin-coated onto glass substrates from chloroform solution and dried to give thin films. The films were then irradiated at $254 \mathrm{~nm}$ using a mercury lamp UV-lamp for 10 minutes to induce photochemical cross-linking, which was then investigated by a solvent resistance test. The glass substrates with the polymer films were immersed in hot 1,2dichlorobenzene where only the TQ1 film could be dissolved proving that cross-linking had taken place for the TQ-Br, TQ$\mathbf{N}_{3}$, TQ-Vinyl and TQ-Oxetane films. Thin films prepared from blends of the polymers with PCBM in a $1: 1$ ratio (by weight) were tested in the same way. The TQ1:PCBM film was fully soluble while the thin films with TQ-Br, TQ-N 3 , TQ-Vinyl and

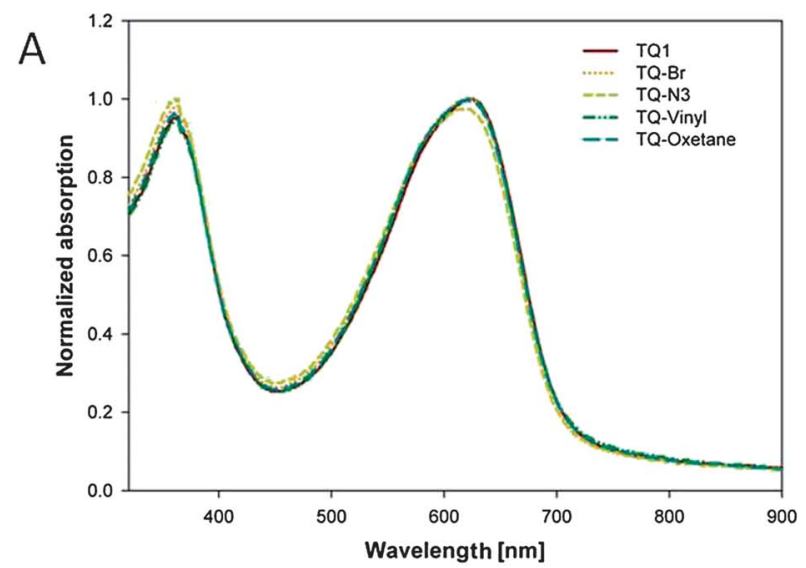

Fig. 1 UV-vis spectra of TQ1, TQ-Br, TQ-N 3 , TQ-Vinyl and TQ-Oxetane films before (A) and after (B) cross-linking by UV irradiation for 10 minutes at $254 \mathrm{~nm}$

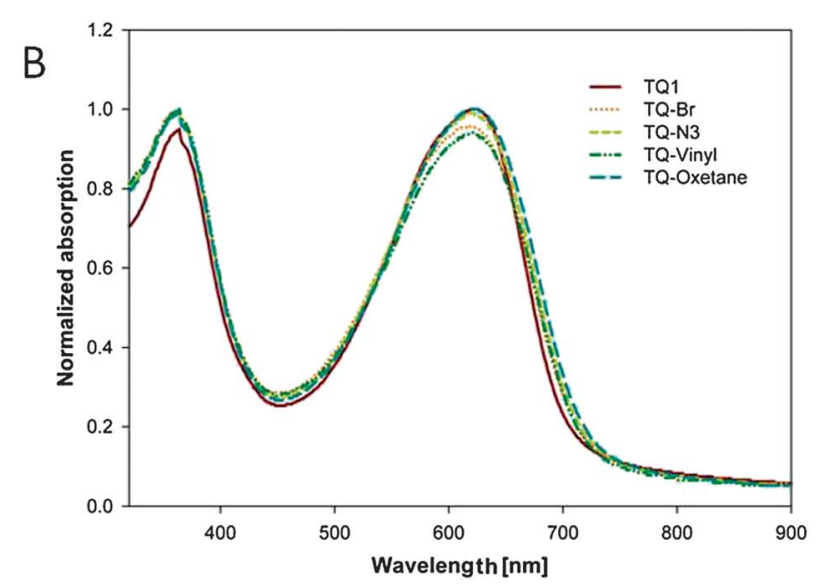

TQ-Oxetane showed partial solvent resistance. PCBM has a strong absorption in the $254 \mathrm{~nm}$ range and therefore absorbs part of the UV light used for cross-linking. This could be a reason for the lower solvent resistance.

Absorption spectra of each polymer were acquired as thin films before and after cross-linking by illumination of the films with UV light. Incorporation of the functional groups does not change the absorption spectra of the polymers when compared to TQ1 (Fig. 1). The spectra of the polymers all have similar features with a $\pi \rightarrow \pi^{*}$ transition at $c a .360 \mathrm{~nm}$ and a charge transfer transition at $\sim 620 \mathrm{~nm}$ (band gap at $1.7 \mathrm{eV}$ ). The absorption spectra of the polymers were essentially unchanged after photocross-linking, showing the same transitions and band gaps as before UV-illumination, which suggests that none of the four different cross-linking reactions damaged the conjugated polymer backbone.

\section{Stability investigations}

Photochemical stability. The photochemical stability of conjugated polymers is dependent on several different parameters such as oxygen concentration, temperature, and the molecular structure. ${ }^{28}$ Incorporation of different functionalities into the polymer could change its stability. Photochemical stabilities of the five polymers were therefore evaluated using a fully automated, high capacity degradation setup with an AM1.5G spectrum in the ambient atmosphere at $1000 \mathrm{~W} \mathrm{~m}^{-2}$ at ambient temperature. ${ }^{22}$ The gradual decrease of UV-vis absorption of the $\sim 60 \mathrm{~nm}$ polymer thin films was spectroscopically monitored during ageing. The normalized absorption versus irradiation time 


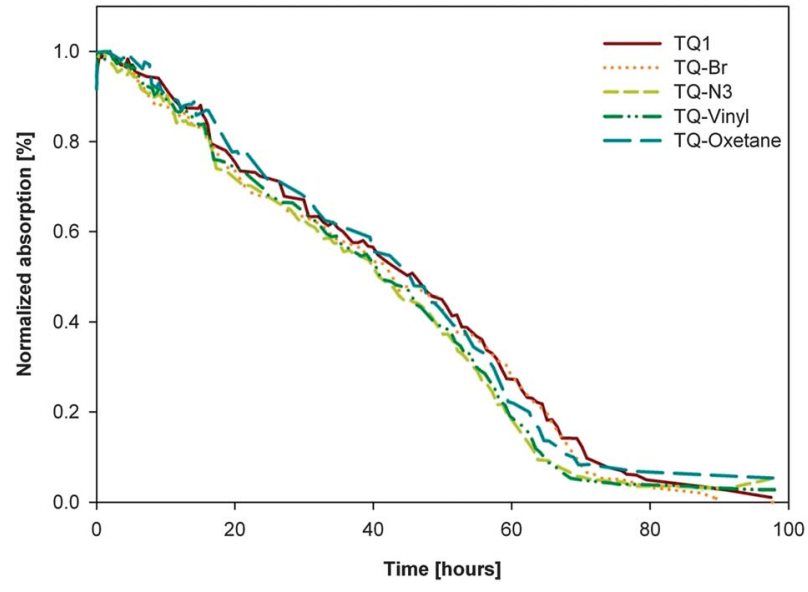

Fig. 2 Photochemical stability of the five polymers as thin films. Normalized absorption versus time under constant illumination (AM1.5G, $1000 \mathrm{~W} \mathrm{~m}^{-2}$ ).

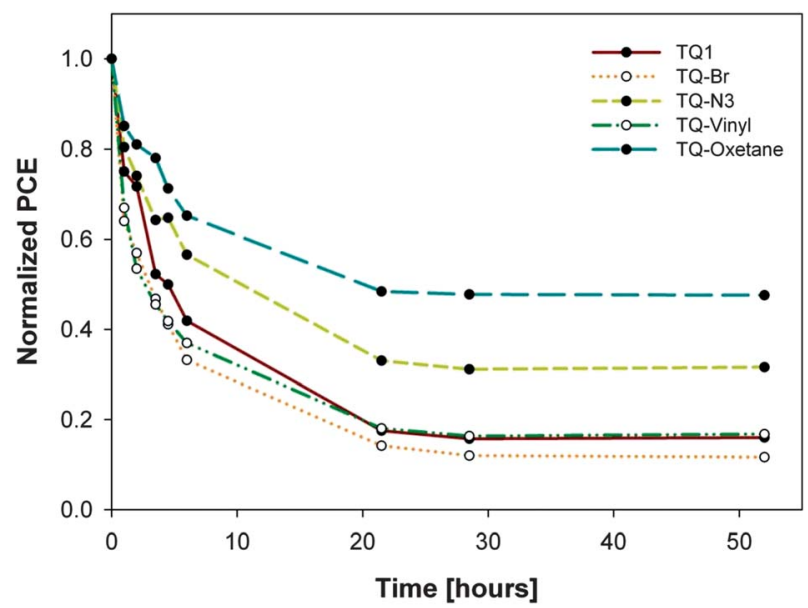

Fig. 3 Efficiencies of devices containing TQ1, TQ-Br, TQ-N 3 , TQ-Vinyl or TQ-Oxetane during thermal annealing at $100{ }^{\circ} \mathrm{C}$ in the dark in an ambient atmosphere (normalized).

for the five polymers is shown in Fig. 2. The degradation rates of the five polymers are almost identical and total bleaching of the films is reached after about 70 hours of illumination. This suggests that incorporation of the functionalities does not affect the photochemical stability of these polymers.
Dark thermal degradation in an ambient atmosphere. One of the tests that has been used to prove the increased stability of devices with cross-linked active layers is thermal annealing with intermittent testing under illumination. This test brings out the degradation due to thermally induced morphology changes such as growth of PCBM domains. Devices with an inverted type geometry (ITO/ZnO/active layer/PEDOT/Ag) were prepared for each of the five polymers and subjected to thermal annealing at $100{ }^{\circ} \mathrm{C}$ for 50 hours. At intervals the $I V$ curves of the devices were measured under illumination (AM1.5G, $1000 \mathrm{~W} \mathrm{~m}^{-2}$ ). As seen in Fig. 3 the devices with TQ-N 3 and TQ-Oxetane degraded to a lesser degree and stabilized at a higher power conversion level than TQ1, TQ-Vinyl and TQ-Br.

The active layer of these devices was further investigated by optical microscopy and atomic force microscopy (AFM) (the AFM images are available in the ESI $\dagger$ ). Each blend was imaged before and after annealing at $150{ }^{\circ} \mathrm{C}$ for 13 hours (see Fig. 4). As expected, large PCBM crystallites formed in the TQ1:PCBM film similar to what has been observed for annealing of P3HT:PCBM. ${ }^{4,5}$ Blends containing TQ-Vinyl, TQ- $\mathbf{N}_{\mathbf{3}}$ and TQOxetane showed either none or only very little phase segregation while the blend containing TQ-Br showed some phase segregation but not to the extent seen for TQ1:PCBM. This confirms that the cross-linking has taken place for all the polymers with incorporated functional groups and that the cross-linking stabilizes the morphology of the BHJ layer towards thermal annealing as has been reported earlier. ${ }^{11-16}$

Constant illumination in ambient atmosphere versus inert atmosphere. Dark thermal degradation reduces the effect of illumination so it is also obvious to investigate device degradation under constant illumination. The results from a study carried out in the ambient atmosphere are shown in Fig. 5a where a similar exponential decay over 17 hours from a maximum to almost no residual efficiency is observed. The cross-linking does not seem to infer any added stability in this case indicating that the dominant degradation mode in this test is photochemical. This observation is consistent with the outcome of the photochemical degradation experiments performed on the pure polymer films that were also unaffected by the cross-linking.

When this study was repeated under inert atmosphere (Fig. 5b), however, the overall rate of degradation was retarded and some differences between the polymers became apparent. A fast initial decay in the performance was once again observed,

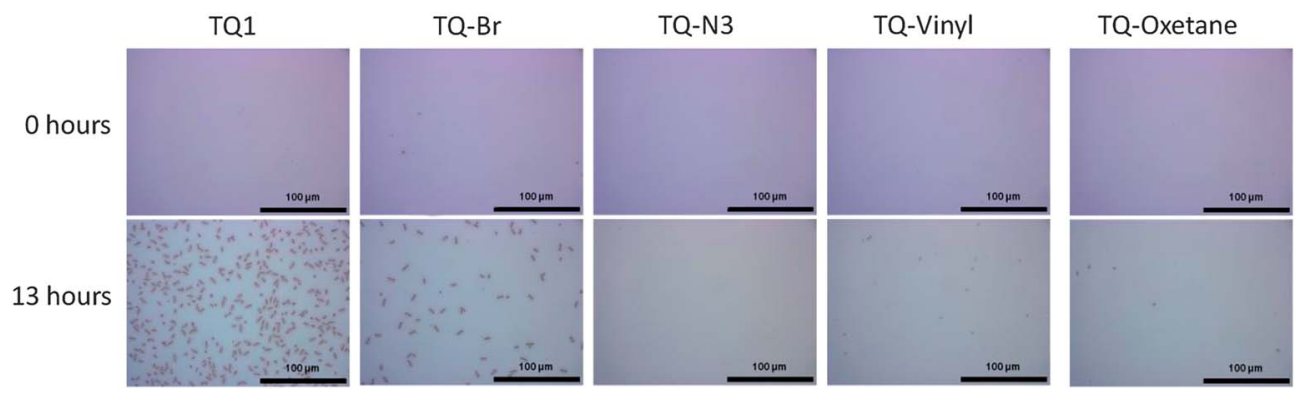

Fig. 4 Optical micrographs $\left(195 \times 260 \mathrm{~mm}^{2}\right)$ of spin-coated thin films of the five polymers blended with PCBM $(1: 1 \mathrm{wt})$ before $(0 \mathrm{hours})$ and after annealing at $150^{\circ} \mathrm{C}$ for 13 hours. All the thin films have been irradiated with UV light at $254 \mathrm{~nm}$ for 10 minutes before recording images. The dark areas correspond to PCBM rich domains. 

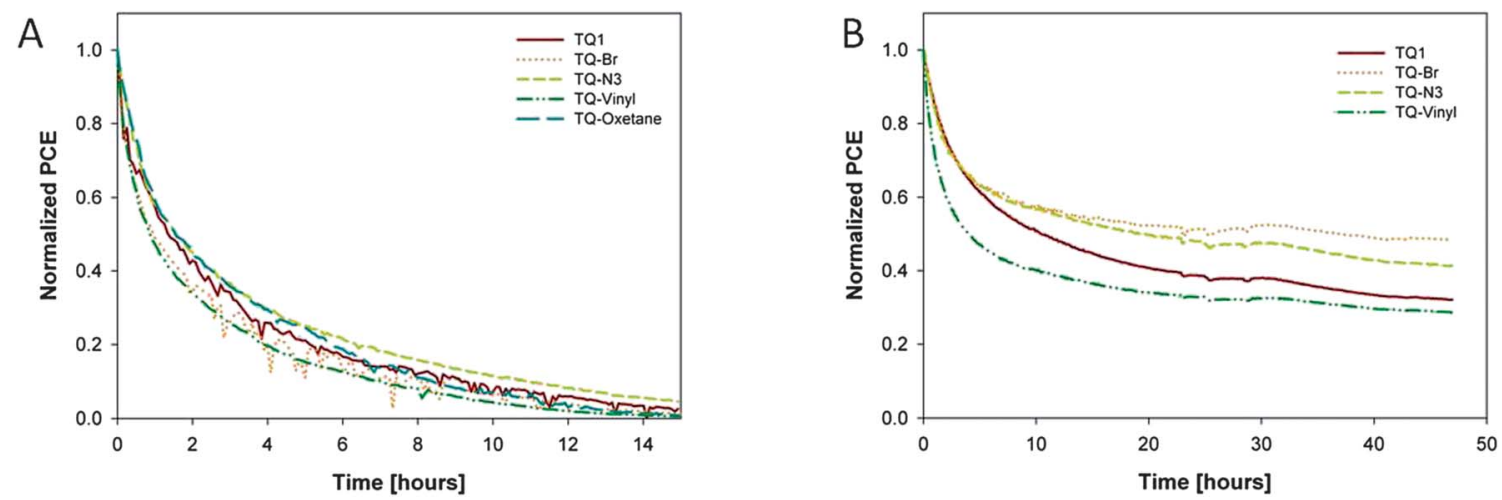

Fig. 5 Deterioration of the power conversion efficiencies of the devices under constant illumination in (A) ambient atmosphere, and in (B) inert atmosphere (normalized).

which could be due to the fact that the devices were fabricated under ambient conditions, which means that they contained a residual amount of oxygen-water. After about 5 hours the decay rate slowed and clear differences in the performance between the different polymers were observed in the order: $\mathbf{T Q}-\mathbf{B r}>\mathbf{T Q}-\mathbf{N}_{\mathbf{3}}>$ TQ1 > TQ-Vinyl.

\section{Conclusions}

This study has shown that different types of cross-linking moieties can be incorporated into the side chains of the low band gap TQ1 type polymer by relatively simple means. The crosslinking reaction could be achieved by UV-irradiation of the pure polymer films to give insoluble products. When PCBM was included the cross-linking was less efficient presumably due to the optical absorption band of PCBM. Some solvent resistance was however observed in this case indicating some degree of cross-linking.

The UV-vis spectra of the polymer films were not affected proving that the cross-linking reaction did not damage the conjugated backbone of the polymers even though widely different reaction types are expected for the four different types of side chain functionalities: bromide, azide, vinyl and oxetane.

Cross-linking was shown to inhibit excessive phase separation and growth of PCBM crystallites in polymer:PCBM films during dark thermal annealing as shown by optical microscopy. This resulted in improved solar cell device stability under the conditions in question. It did, however, not improve the device stability under constant illumination in an ambient atmosphere, which is probably dominated by photochemical degradation rather than by thermal mechanisms. When oxygen-water was excluded by employing an inert atmosphere the stability increased somewhat and more importantly, some differences in stability became apparent between the polymers with $\mathbf{T Q}-\mathbf{B r}$ and TQ-N $\mathbf{N}_{\mathbf{3}}$ giving the most stable devices. At present no explanation is provided for this observed difference, but it could be ascribed to different cross-linking mechanisms and also to different reaction rates.

This study shows that cross-linking can improve morphological stability, but that other factors such as photochemical degradation might be more important for device stability under constant illumination conditions.

\section{Acknowledgements}

This work has been supported by the Danish Strategic Research Council (2104-07-0022), EUDP (j.no. 64009-0050 and 640110002), the Danish National Research Foundation, and from PVERA-NET (project acronym POLYSTAR).

\section{Notes and references}

1 T. Chu, J. Lu, S. Beaupré, Y. Zhang, J. Pouliot, S. Wakim, J. Zhou, M. Leclerc, Z. Li, J. Ding and Y. Tao, J. Am. Chem. Soc., 2011, 133, 4250.

2 H. Chen, J. Hou, S. Zhang, Y. Liang, G. Yang, Y. Yang, L. Yu, Y. Wu and G. Li, Nat. Photonics, 2009, 3, 649.

3 M. Jørgensen, K. Norrman, S. A. Gevorgyan, T. Tromholt, B. Andreasen and F. C. Krebs, Adv. Mater., 2012, 24, 580.

4 S. Bertho, G. Janssen, T. J. Cleij, B. Conings, W. Moons, A. Gadisa, J. D'Haen, E. Goovaerts, L. Lutsen, J. Manca and D. Vanderzande, Sol. Energy Mater. Sol. Cells, 2008, 92, 753.

5 M. Drees, H. Hoppe, C. Winder, H. Neugebauer, N. S. Sariciftci, W. Schwinger, F. Schäffler, C. Topf, M. C. Scharber, Z. Zhu and R. Gaudiana, J. Mater. Chem., 2005, 15, 5158.

6 P. D. Topham, A. J. Parnell and R. C. Hiorns, J. Polym. Sci., Part B: Polym. Phys., 2011, 49, 1131.

7 G. Ren, P.-T. Wu and S. A. Jenekhe, Chem. Mater., 2010, 22, 2020.

8 E. J. W. Crossland, M. Kamperman, M. Nedelcu, C. Ducati, U. Wiesner, D. M. Smilgies, G. E. S. Toombes, M. A. Hillmyer, S. Ludwigs, U. Steiner and H. J. Snaith, Nano Lett., 2009, 9, 2807.

9 J. Liu, E. N. Kadnikova, Y. Liu, M. D. McGehee and J. M. J. Frechét, J. Am. Chem. Soc., 2004, 126, 9486.

10 J. Farinhas, Q. Ferriera, R. E. Di Paolo, L. Alcácer, J. Morgado and A. Charas, J. Mater. Chem., 2011, 21, 12511.

11 B. J. Kim, Y. Miyamoto, B. Ma and J. M. J. Frechét, Adv. Funct. Mater., 2009, 19, 2273.

12 G. Griffini, J. D. Douglas, C. Piliego, T. W. Holcombe, S. Turri, J. M. J. Frechét and J. L. Mynar, Adv. Mater., 2011, 23, 1660.

13 B. Gholamkhass and S. Holdcroft, Chem. Mater., 2010, 22, 5371.

14 H. J. Kim, A. R. Han, C. H. Cho, H. Kang, H. H. Cho, M. Y. Lee, J. M. J. Frechét, J. H. Oh and B. J. Kim, Chem. Mater., 2012, 24, 215.

15 C. Y. Nam, Y. Qin, Y. S. Park, H. Hlaing, X. Lu, B. M. Ocko, C. T. Black and R. B. Grubbs, Macromolecules, 2012, 45, 2338.

16 C. H. Hsieh, Y. J. Cheng, P. J. Li, C. H. Chen, M. Dubosc, R. M. Liang and C. S. Hsu, J. Am. Chem. Soc., 2010, 132, 4887.

17 U. R. Lee, T. W. Lee, M. H. Hoang, N. S. Kang, J. W. Yu, K. H. Kim, K. G. Lim, T. W. Lee, J. I. Jin and D. H. Choi, Org. Electron., 2011, 12, 269.

18 T. Yamamoto, B. L. Lee, H. Kokubo, H. Kishida, K. Hirota, T. Wakabayashi and H. Okamoto, Macromol. Rapid Commun., 2003, 24, 440.

19 E. Wang, L. Hou, Z. Wang, S. Hellström, F. Zhang, O. Inganäs and M. R. Andersson, Adv. Mater., 2010, 22, 5240.

20 M. Helgesen, S. A. Gevorgyan, F. C. Krebs and R. A. J. Janssen, Chem. Mater., 2009, 21, 4669. 
21 W. J. E. Beek, M. M. Wienk, M. Kemerink, X. Yang and R. A. J. Janssen, J. Phys. Chem. B, 2005, 109, 9505.

22 T. Tromholt, M. V. Madsen, J. E. Carlé, M. Helgesen and F. C. Krebs, J. Mater. Chem., 2012, 22, 7592.

23 K. S. Lee, K. Y. Yeon, K. H. Jung and S. K. Kim, J. Phys. Chem. A, 2008, 112, 9312.

24 R. F. Klima and A. D. Gudmundsdóttir, J. Photochem. Photobiol., A, 2004, 162, 239.
25 K. A. Murray, A. B. Holmes, S. C. Moratti and G. Rumbles, J. Mater. Chem., 1999, 9, 2109.

26 N. Yasuda, S. Yamamoto, Y. Wada and S. Yanagida, J. Polym. Sci., Part A: Polym. Chem., 2001, 39, 4196.

27 S. Feser and K. Meerholz, Chem. Mater., 2011, 23, 5001.

28 M. Manceau, E. Bundgaard, J. E. Carlé, O. Hagemann, M. Helgesen, R. Søndergaard, M. Jørgensen and F. C. Krebs, J. Mater. Chem., 2011, 21, 4132. 